\title{
Alternative end scenarios for the LCA analysis of a steel-framed residential building
}

\author{
I. Zygomalas \\ Department of Civil Engineering, Aristotle University of Thessaloniki (AUTH), Thessaloniki, Greece
}

D. N. Kaziolas

Eastern Macedonia and Thrace Institute of Technology, Kavala, Greece

G. E. Stavroulakis

Department of Production Engineering and Management, Technical University of Crete, Chania, Greece

E. Zacharenakis

Technological Educational Institute of Crete, Heraklion, Greece

E. Efthymiou

Department of Civil Engineering, AUTH, Thessaloniki, Greece

C.C. Baniotopoulos

Department of Civil Engineering, AUTH, Thessaloniki, Greece; School of Civil Engineering, The University of Birmingham, United Kingdom

ABSTRACT: Life Cycle Assessment (LCA) is currently being widely used within the construction sector as the most accurate and effective methodology to quantify the environmental impact associated with construction projects. Taking into account project stages such as raw material acquisition, construction, operation and the handling of the materials at the demolition stage, it constitutes a valuable tool to optimize the sustainability of technical structures. The purpose of the current research is to investigate the last stage of a project considered in LCA analysis, namely the end scenario. A steel-framed residential building is used as the basis for the definition of a set of alternative end scenarios which cover the complete range of handling options for the construction materials retrieved after the service life of the building. These scenarios are used to complement a corresponding set of alternative life cycles, for which environmental impact assessment calculations are executed. The results are used to draw conclusions regarding the influence of end scenarios and material handling at the end of a construction project on the minimization of its environmental impact and the subsequent optimization of its sustainability.

\section{INTRODUCTION}

The principles of sustainable development have been and are still being embedded in the practices applied within business sectors across the economic market. The aim is to minimize the environmental impact caused by the activities and/or products of each sector, especially of those that have been identified as the largest consumers of energy and natural resources. Construction is understandably one of these very sectors, as it requires massive amounts of materials and energy in order to deliver the numerous small or large-scale projects commissioned. It is therefore important to accelerate the application of research findings regarding the sustainability of construction projects, so as to minimize their environmental impact as much and as soon as possible (Bragança et al., 2007).

Life cycle assessment (LCA) has been introduced and is currently acknowledged as the reference methodology to approach these issues. It is used extensively within many types of sectors, including construction (ISO, 2006a and 2006b). Its structure and application are well-defined and can be applied to construction projects such as buildings, bridges or any other type of project for which an environmental impact assessment is required.

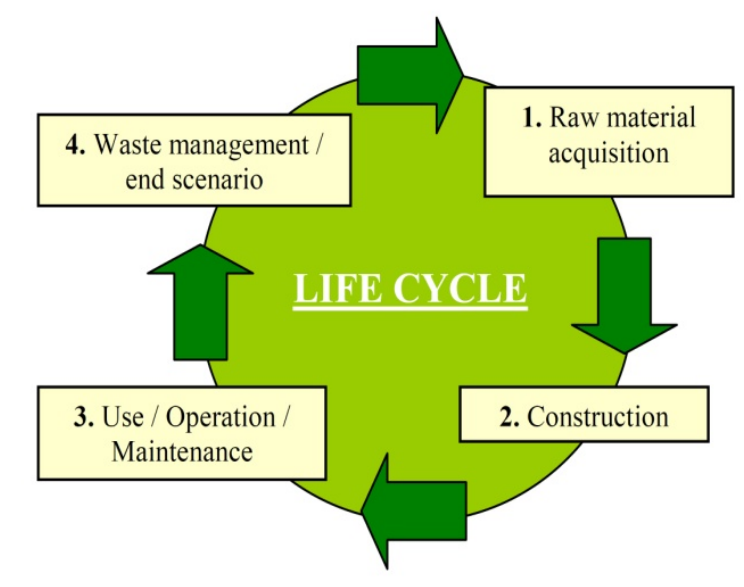

Figure 1. The four main stages of a construction project's life cycle (Zygomalas and Baniotopoulos, 2013)

The methodology is based on the concept of the life cycle and for construction projects, the life cycle 
of each project includes four stages (Figure 1), namely the raw material acquisition stage, the construction stage, the operation/use/maintenance stage and the demolition stage (Kaziolas et al., 2013). The first stage refers to the use of natural resources required for the manufacturing of the materials necessary for the project. The construction stage takes in to account all the construction process carried out, while the third stage refers to the actual operation or use of the structure, including any maintenance processes carried out. The final stage of a project's life cycle refers to the handling of the materials retrieved after the decision for its demolition has been made.

\section{METHODOLOGY}

It is the end-of-life stage that the current research focuses on, as it constitutes one of the life cycle stages of construction projects that hold increased potential for environmental impact minimization. Many construction material manufacturers have acknowledged the need for the minimizing the environmental impact of their products and have thus designed their products with recycling and reuse as a priority. However, if not planned for or if not taken into account these capabilities can very easily go unexploited. The aim of this research is to investigate the environmental impact associated with a set of alternative end scenarios, referring to differing handling options for the retrieved materials at the end of a project's service life.

A steel-framed residential building is used as the basis for the definition of the alternative end scenarios and the environmental impact calculations. It is a ground-floor single-storey residence with a steel load-bearing frame and reinforced concrete slabs and foundation as displayed in Figure 2.

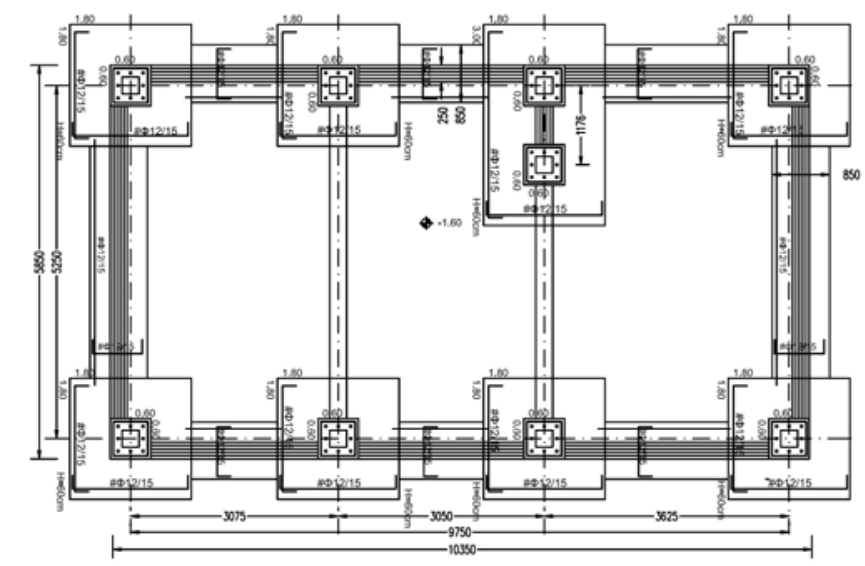

Figure 2. Plan view of foundation level of steel-framed residential building.

Structural steel is a material that can be both recycled and reused and is therefore suitable for investigating the environmental impact of different waste treatment alternatives as the results obtained are ex- pected to display potential differences to a more visible degree (Zygomalas et al., 2012). The processes and quantities of materials required for the construction of the steel building were documented and used to carry out the LCA analyses for the current research. The construction materials taken into account are listed in Table1.

Table 1. Main materials and processes for the construction of the steel building

\begin{tabular}{ccc}
\hline Main materials and processes & Unit & Quantity \\
\hline Structural steel sections & $\mathrm{kg}$ & 6862.6 \\
Steel connection elements & $\mathrm{kg}$ & 1364.1 \\
Concrete & $\mathrm{m}^{3}$ & 51.1 \\
Steel reinforcement for concrete & $\mathrm{kg}$ & 3760.3 \\
Excavation & $\mathrm{m}^{3}$ & 161.6 \\
Steel sheet profile for deck & $\mathrm{kg}$ & 217 \\
\hline
\end{tabular}

\section{ALTERNATIVE END SCENARIOS}

The capacity of structural steel for recycling stems from its property to be melted and remoulded -with the proper substance additions- into new steel products that do not compromise the quality of the material. Its potential for reuse is another sustainable option, as structural steel members that are investigated and found not to carry significant wear can be used "as is" in other structures. This route avoids the need for the remanufacturing of the new quantity of steel as the final product is already available and as a result, the environmental impact of the material is greatly reduced. For the current LCA analysis three end scenarios were assumed, each corresponding to a different way of handling the retrieved materials at the end of the steel-framed building's service life.

Table 2. End-of-life scenarios developed for the handling of the retrieved materials

\begin{tabular}{|c|c|}
\hline $\begin{array}{c}\text { End } \\
\text { scenario }\end{array}$ & Waste treatment \\
\hline Recycling & $\begin{array}{l}90 \% \text { of structural and reinforcing steel recycled } \\
10 \% \text { considered irretrievable and disposed in landfill } \\
80 \% \text { of the concrete recycled (crushed to be used as } \\
\text { gravel) } \\
20 \% \text { considered irretrievable and disposed in landfill }\end{array}$ \\
\hline Reuse & $\begin{array}{l}60 \% \text { of structural and reinforcing steel reused } \\
30 \% \text { recycled } \\
10 \% \text { considered irretrievable and disposed in landfill } \\
80 \% \text { of the concrete recycled (crushed to be used as } \\
\text { gravel) } \\
20 \% \text { considered irretrievable and disposed in landfill }\end{array}$ \\
\hline Landfill & $\begin{array}{l}30 \% \text { of structural and reinforcing steel recycled } \\
70 \% \text { considered irretrievable and disposed in landfill } \\
30 \% \text { of the concrete recycled (crushed to be used as } \\
\text { gravel) } \\
70 \% \text { considered irretrievable and disposed in landfill }\end{array}$ \\
\hline
\end{tabular}


The first scenario refers to the recycling of the retrieved construction materials, the second one to their reuse and the third to their disposal in landfills. All three end scenarios were developed with the aim to quantify the environmental impact of each waste treatment and therefore illustrate their sustainability potential. The assumptions taken into account for each end scenario are presented in Table 2.

\section{LIFE CYCLE INVENTORY (LCI)}

Each process and material quantity associated with the life cycle of the steel building is used for the creation of a list of environmental inputs and outputs, corresponding to the resources used and substances emitted to the environment respectively. This list contains more than 800 entries in total and a selection of the most important substances to be monitored (European Environment Agency, 2007) is presented in Table 3. The negative values refer to the beneficial influence of recycling or reuse taking place according to each end scenario.

Table 3. Life Cycle Inventory (LCI) of the alternative end scenario life cycles of the steel building

\begin{tabular}{|c|c|c|c|c|c|}
\hline Substance & Category & Unit & $\begin{array}{r}\text { Life cycle } \\
\text { (Recycling) }\end{array}$ & $\begin{array}{r}\text { Life cycle } \\
\text { (Reuse) }\end{array}$ & $\begin{array}{l}\text { Life eycle } \\
\text { (Landfill) }\end{array}$ \\
\hline Coal (brown, in ground) & Raw material & $\mathrm{kg}$ & 13056,57 & 10415,03 & 13274,07 \\
\hline Dolomite $\left(\mathrm{CaCO}_{3}\right.$, in grou & Raw material & $\mathrm{kg}$ & 2,622847 & $-11,055$ & 2,8984 \\
\hline $\begin{array}{l}\text { Iron ( } 46 \% \text { in ore, } 25 \% \text { in crude ore, } \\
\text { in ground) }\end{array}$ & Raw material & $\mathrm{kg}$ & $-9784,39$ & $-8252,13$ & $-2465,46$ \\
\hline Manganese $(\mathrm{Mn}, 35.7 \%$ in & & & & & \\
\hline $\begin{array}{l}\text { sedimentary deposit, } 14.2 \% \\
\text { ore }\end{array}$ & Raw material & $\mathrm{kg}$ & & & \\
\hline $\begin{array}{l}\text { ore, in ground) } \\
\text { oil (crude, in ground) }\end{array}$ & & & $\begin{array}{r}0,310217 \\
183603\end{array}$ & $\begin{array}{r}0,184621 \\
153284\end{array}$ & $\begin{array}{r}0,56685 \\
2300.662\end{array}$ \\
\hline $\begin{array}{l}\text { il) (crude, in ground) } \\
\text { Water (enspecified natural origin) }\end{array}$ & $\begin{array}{l}\text { Raw material } \\
\text { Raw material }\end{array}$ & $\mathrm{kg}^{3}$ & $\begin{array}{r}1836,03 \\
77,27323\end{array}$ & $\begin{array}{r}1536,284 \\
2650472\end{array}$ & $\begin{array}{l}2300,662 \\
206,1421\end{array}$ \\
\hline $\begin{array}{l}\text { Water (unspecififed natural origin) } \\
Z \text { Zinc ( } \mathrm{Zn} \text {, in ground) }\end{array}$ & $\begin{array}{l}\text { Raw material } \\
\text { Raw material }\end{array}$ & $\begin{array}{l}\mathrm{m} \\
\mathrm{kg}\end{array}$ & $\begin{array}{l}7,2,27323 \\
3,06 \mathrm{E}-05\end{array}$ & $1,68 \mathrm{E}-05$ & $\begin{array}{l}206,1421 \\
3,06 \mathrm{E}-05\end{array}$ \\
\hline Carbon dioxide $\left(\mathrm{CO}_{2}\right)$ & Air emission & $\mathrm{kg}$ & 3227,882 & 2254,412 & 3227,882 \\
\hline Carbon dioxide, fossil $\left(\mathrm{CO}_{2}\right)$ & Air emission & $\mathrm{kg}$ & 21721,62 & 17249,35 & 29951,33 \\
\hline Carbon monoxide $(\mathrm{CO})$ & Air emission & $\mathrm{kg}$ & 44,12758 & 43,7299 & 44,12758 \\
\hline Carbon monoxide, fossil (CO) & Air emission & $\mathrm{kg}$ & & $\begin{array}{r}-196,28 \\
0215751\end{array}$ & $-29,2296$ \\
\hline 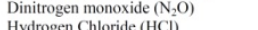 & Air emission & $\mathrm{kg}$ & 0,319522 & 0,215751 & 0,38776 \\
\hline $\begin{array}{l}\text { Hydrogen Chloride }(\mathrm{HCl}) \\
\text { Hydrogen Sulphide }(\mathrm{H} \text { S }\end{array}$ & $\begin{array}{l}\text { Air emission } \\
\text { Airemission }\end{array}$ & $\mathrm{kg}$ & $\begin{array}{l}2,804202 \\
-0.18464\end{array}$ & $\begin{array}{l}2,170324 \\
-0.17292\end{array}$ & $\begin{array}{l}3,191181 \\
-00657\end{array}$ \\
\hline $\begin{array}{l}\left.\text { Hydrogen Sulphide ( } \mathrm{H}_{2} \mathrm{~S}\right) \\
\text { Lead (Pb) }\end{array}$ & $\begin{array}{l}\text { Air emission } \\
\text { Air emission }\end{array}$ & $\begin{array}{l}\mathrm{kg} \\
\mathrm{kg}\end{array}$ & $\begin{array}{r}-0,18464 \\
-0.01632\end{array}$ & $\begin{array}{r}-0.177292 \\
-0.0247\end{array}$ & $\begin{array}{l}-0,00657 \\
0,003933\end{array}$ \\
\hline $\begin{array}{l}\text { Lead (Pb) } \\
\text { Mercury }(\mathrm{Hg}\end{array}$ & $\begin{array}{l}\text { Air emisssion } \\
\text { Air emission }\end{array}$ & $\begin{array}{l}\mathrm{kg} \\
\mathrm{kg}\end{array}$ & $\begin{array}{l}-0,000749 \\
0,0079\end{array}$ & $\begin{aligned}-0,0047 \\
-0,00595\end{aligned}$ & $\begin{array}{l}0,0009333 \\
0,001291\end{array}$ \\
\hline Methane ( $\mathrm{CH}_{4}$, fossil) & Air emission & $\mathrm{kg}$ & 4,941774 & 2,429593 & 4,941774 \\
\hline Nitrogen oxides $\left(\mathrm{NO}_{\mathrm{x}}\right)$ & Air emission & $\mathrm{kg}$ & 37,84439 & 30,22335 & 59,76458 \\
\hline $\begin{array}{l}\text { Non-methanane volatite organic } \\
\text { compounds (NMVOC) }\end{array}$ & Air emission & $\mathrm{kg}$ & 10,88984 & & \\
\hline Particulates, $<2.5$ um $\left(\mathrm{PM}_{2.5}\right)$ & Air emission & $\mathrm{kg}$ & 1,48 & & 7,296682 \\
\hline Particulates, $<10 \mathrm{um}\left(\mathrm{PM}_{10}\right)$ & Air emission & & 0,006463 & 0,005493 & 0,006463 \\
\hline Sulfur dioxide $\left(\mathrm{SO}_{2}\right)$ & Air emission & $\mathrm{kg}$ & 43,52497 & 31,23939 & 61,99601 \\
\hline Sulfur oxides $\left(\mathrm{SO}_{\mathrm{x}}\right)$ & Air emission & $\mathrm{kg}$ & & 0,589405 & 1,185597 \\
\hline Zinc $(2$ & Air emission & $\mathrm{kg}$ & 81 & $-0,03238$ & 0,052598 \\
\hline Cadmium, ion & Water emission & $\mathrm{kg}$ & 29 & 0,014883 & 0,026944 \\
\hline Chemical Oxygen Demand (COD) & Water emission & $\mathrm{kg}$ & 19 & $\begin{array}{l}-3,72204 \\
0.0318\end{array}$ & 27,85823 \\
\hline $\begin{array}{l}\text { Chromium, ion } \\
\text { Iron }\end{array}$ & $\begin{array}{l}\text { Water emission } \\
\text { Water emission }\end{array}$ & $\begin{array}{l}\mathrm{kg} \\
\mathrm{kg}\end{array}$ & $\begin{array}{l}0,010071 \\
0,056764\end{array}$ & $\begin{array}{l}0,003818 \\
0,027876\end{array}$ & $\begin{array}{l}0,010196 \\
0.056764\end{array}$ \\
\hline $\begin{array}{l}\text { Iron } \\
\text { Lead (Pb) }\end{array}$ & $\begin{array}{l}\text { Water emisssion } \\
\text { Water emission }\end{array}$ & $\begin{array}{l}\mathrm{kg} \\
\mathrm{kg}\end{array}$ & $\begin{array}{l}0,056764 \\
0,059168\end{array}$ & $\begin{array}{l}0,027776 \\
0,03259\end{array}$ & $\begin{array}{l}0,056664 \\
0,06274\end{array}$ \\
\hline Nickel, ion & Water emission & $\begin{array}{l}\mathrm{kg} \\
\mathrm{kg}\end{array}$ & $\begin{array}{l}2,796057 \\
2,700\end{array}$ & 1,462741 & 3,152766 \\
\hline Suspended solids & Water emission & $\mathrm{kg}$ & & 0,166311 & 4,2161 \\
\hline Zinc, ion & Water emission & $\mathrm{kg}$ & 2,445924 & 1,725553 & 2,904809 \\
\hline Calcium & Soil emission & $\mathrm{kg}$ & $\begin{array}{r}0,26721 \\
076\end{array}$ & 0,167917 & $\begin{array}{l}0,314369 \\
207208\end{array}$ \\
\hline $\begin{array}{l}\text { Heat, waste } \\
\text { tron }\end{array}$ & $\begin{array}{l}\text { Soil emission } \\
\text { Solemission }\end{array}$ & MJ & 197,6113 & $\begin{array}{l}112,3888 \\
0.02072\end{array}$ & $\begin{array}{l}227,2308 \\
024546\end{array}$ \\
\hline $\begin{array}{l}\text { Iron } \\
\text { Oils }\end{array}$ & $\begin{array}{l}\text { Soll emission } \\
\text { Soil emission }\end{array}$ & $\begin{array}{l}\mathrm{kg} \\
\mathrm{kg}\end{array}$ & $\begin{array}{l}-0,04002 \\
4,845755\end{array}$ & $\begin{array}{l}-0,20372 \\
3,78345\end{array}$ & $\begin{array}{l}0,243546 \\
6,115477\end{array}$ \\
\hline
\end{tabular}

\section{LIFE CYCLE ASSESSMENT (LCA)}

The goal of the current LCA analyses is the quantification of the environmental impact caused by the life cycle of the steel-framed residential building for each of the alternative life cycles created with the corresponding alternative end scenarios. The analyses include the acquisition of the raw materials for the manufacturing of the necessary construction ma- terials, their transport to the site, the construction of the building and the handling of the retrieved materials at the end of the service life of the building. For the transport of the materials to the various end-oflife facilities (sorting plants, recycling plants, landfills etc.) a $30 \mathrm{~km}$ transport distance is taken into account, while the distance assumed for the transport of the materials to the site at the construction stage of the building is $10 \mathrm{~km}$. The functional unit for the LCA is the construction of the steel-framed residence, while the geographic coverage refers to the Greek and European region. For the environmental impact assessment, the Eco-Indicator 99 (Ecoindicator 99 (E) V2.08 / Europe EI 99 E/E) methodology is used and the environmental impact is thus calculated in Eco-Indicator points $(\mathrm{Pt})$, where $1 \mathrm{Pt}$ is representative of one thousandth of the yearly genvironmental load of one average European inhabitant (The Netherlands Ministry of Housing, Spatial Planning and the Environment, 2000).

\subsection{Recycling end scenario}

The environmental impact caused by the life cycle of the steel-framed building taking into account the recycling end scenario is presented in Figure 3. As can be observed, the impact caused by the construction of the building is $2377 \mathrm{Pt}$, while the benefits provided by the end scenario were calculated at $1431 \mathrm{Pt}$ (the negative value refers to environmental benefit).

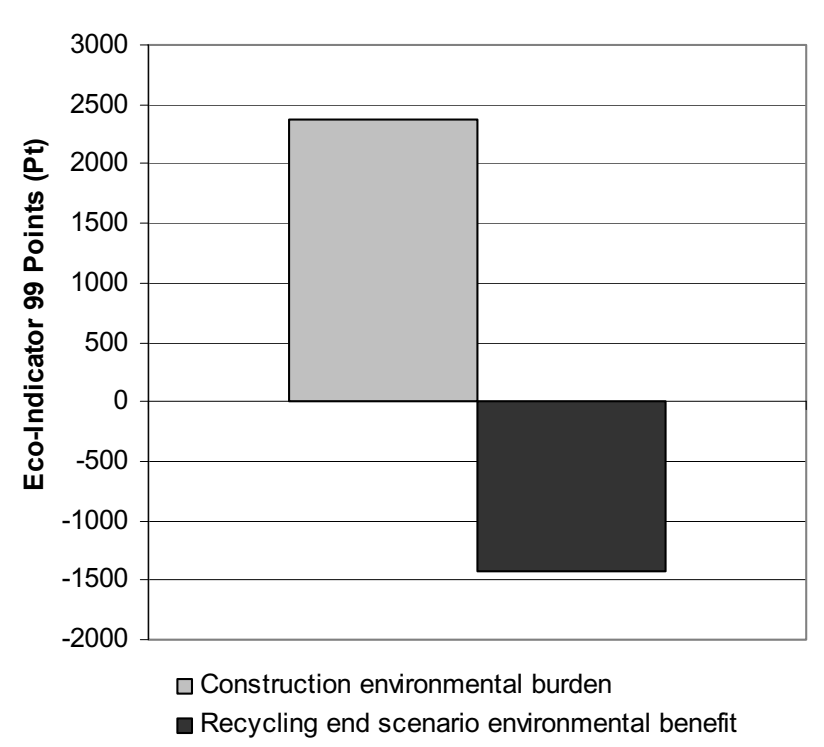

Figure 3. Environmental impact of the construction and recycling end scenario for the steel building

The beneficial influence of the recycling of the materials is evident, since it reduces the impact of the building's construction by more than half. Further analysis of the end scenario environmental benefits show that it is the steel elements that are responsible for the largest percentage of benefits 
provided. The recycling of steel elements can therefore play a significant role in ensuring the sustainability of construction projects, since it removes the need for the extraction of new quantities of raw materials by utilizing steel and iron scrap that would otherwise be disposed of.

\subsection{Reuse end scenario}

The reuse end scenario life cycle causes the environmental impact displayed in Figure 4. The impact caused by the construction of the building is the same, at $2377 \mathrm{Pt}$, while the benefits provided by the reuse end scenario were calculated at $-1947 \mathrm{Pt}$. The beneficial influence of the reuse of the steel elements leads to remarkable environmental benefits that almost match the impact caused by the construction of the residential building. As expected, these benefits are the result of the fact that reuse avoids the manufacturing processes required for recycling and is thus capable of providing even greater environmental benefits.

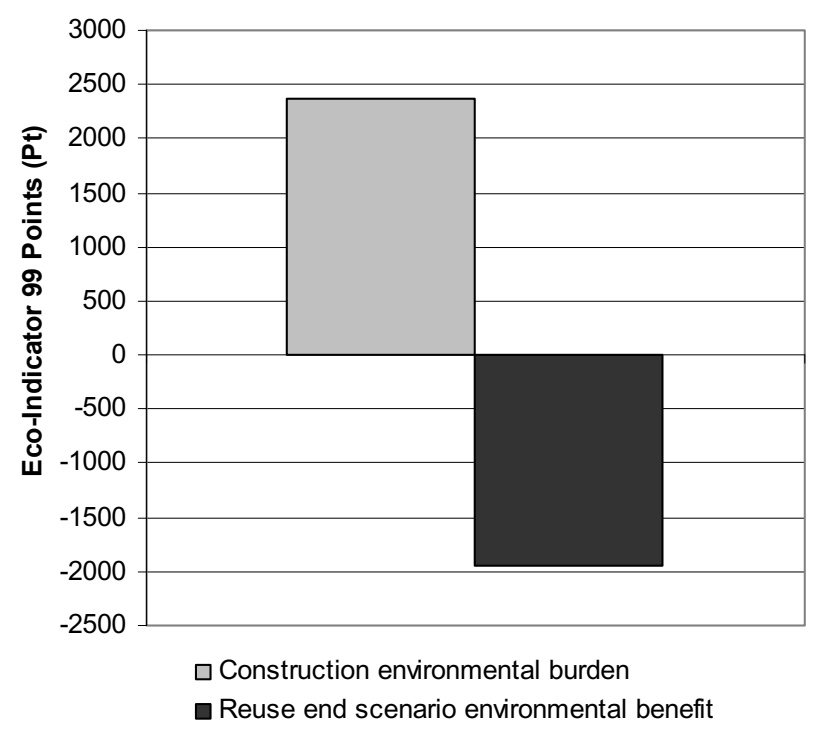

Figure 4. Environmental impact of the construction and reuse end scenario for the steel building

These results show that reuse is the optimal end scenario -even in comparison to recycling. As far as a construction project's design is concerned, it would therefore be preferable to include provisions that will enable the maximization of construction material reuse when the service life of the project has ended.

\subsection{Landfill end scenario}

The environmental impact caused by the life cycle of the steel-framed building with the landfill end scenario is presented in Figure 5. The impact caused by the construction of the building is again $2377 \mathrm{Pt}$, while the benefits provided by the end scenario were calculated at only $-399 \mathrm{Pt}$. These quite smaller benefits are attributed to the small quantities of materials recycled and the fact that the disposal of the remaining materials in landfills causes significant burden rather than benefits. It is therefore obvious that landfill disposal does not only cause additional environmental burden -which noticeably decreases any recycling benefits- but also prevents potential benefits that could be obtained by other material treatments such as recycling or reuse.

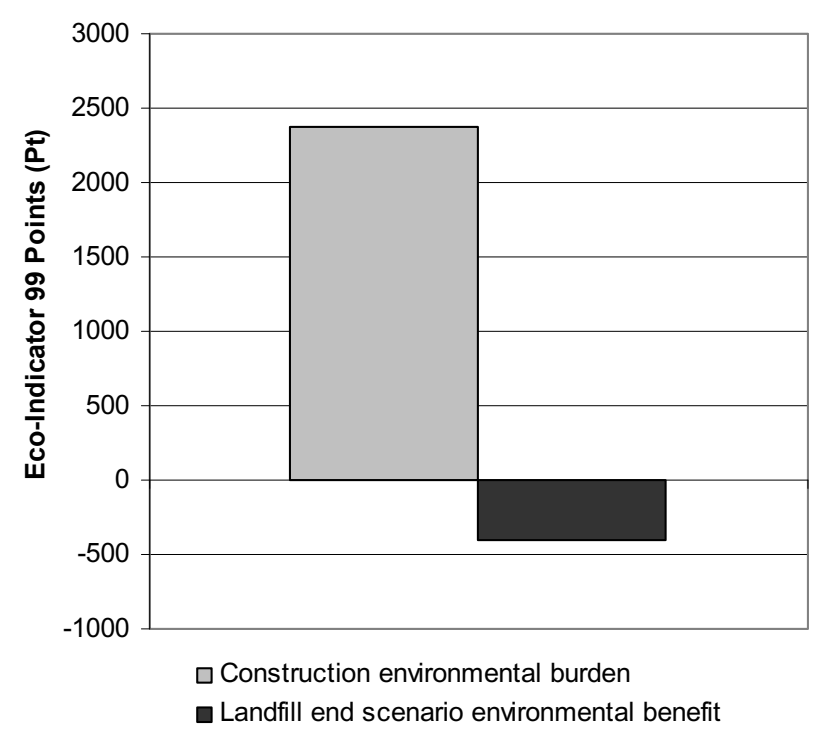

Figure 5. Environmental impact of the construction and landfill end scenario for the steel building

\subsection{Environmental impact indicators}

The results obtained by the current LCA analyses also refer to the impact of the steel building's alternative life cycles on the environmental indicators used by the Eco-Indicator 99 methodology. In Figure 6 these results are displayed for the construction of the building and the three alternative end scenarios examined. The environmental indicators cover a wide range of environmental issues, from human health (e.g. carcinogens and respiratory inorganics) and natural resources (e.g. fossil fuels) to the quality of the eco-system (e.g. climate change and ecotoxicity).

As can be observed, the construction of the steelframed building primarily burdens the 'fossil fuels' indicator which refers to the quality of the available fossil fuel reserves. Secondly, it affects human health ('respiratory inorganics' and 'carcinogens' indicators) and climate change. On the other hand, the end scenarios provide a mixture of environmental impacts; recycling and reuse provide remarkable benefits for the 'respiratory inorganics' indicator, even surpassing the burden caused by the building's construction. A similar situation is observed for the 'fossil fuels' indicator, where recycling and reuse again provide noticeable benefits corresponding to about half of the impact created by construction. As expected, the landfill scenario provides almost neg- 
ligible benefits, due to the environmental burden created by the disposal of materials in landfills.

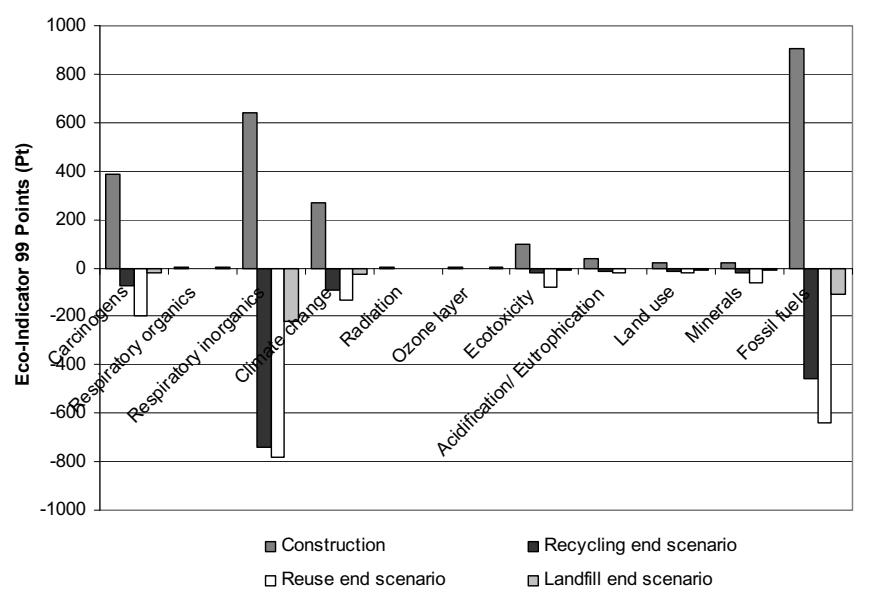

Figure 6. Impact of the steel building's life cycles on the EcoIndicator 99 environmental indicators

\section{CONCLUSIONS}

The current research aimed to investigate the last stage in the life cycle of construction projects which refers to the handling of the retrieved materials after the decision for demolition has been made. Three alternative end scenarios were defined, covering available material handling options such as recycling, reuse and landfill disposal and a steel-framed residential building was used as the basis for the calculations. The results obtained include a detailed list of environmental inputs and outputs as well as environmental impact results for each of the three respective alternative life cycles of the steel building. The recycling scenario was shown to have a very beneficial influence, reducing the environmental impact of the building's construction by more than half. The reuse scenario led to even more remarkable environmental benefits, almost matching the impact of the building's construction. This was attributed to the fact that reuse avoids any manufacturing processes altogether and is thus capable of providing even greater environmental benefits than recycling. It is therefore suggested that reuse is the optimal end scenario; it should be considered at a construction project's design stage so that provisions that will enable the maximization of construction material reuse when the service life of the project has ended can be taken into account. In regard to landfill disposal, it was shown that this waste treatment does not only cause additional environmental burden but also prevents potential benefits that could be obtained by other material treatments such as recycling or reuse.

\section{ACKNOWLEDGMENTS}

This research has been co-financed by the European Union (European Social Fund - ESF) and
Greek national funds through the Operational Program "Education and Lifelong Learning" of the National Strategic Reference Framework (NSRF) - Research Funding Program: ARCHIMEDES III. Investing in knowledge society through the European Social Fund.

\section{REFERENCES}

Bragança, L., Mateus, R. and Koukkari H. 2007. "Perspectives of building sustainability assessment". In: Bragança, L., Pinheiro, M.D., Jalali, S., Mateus, R., Amoêda, R. and Guedes, M.C. (editors). Portugal SB07 - Sustainable construction, materials and practices, IOS Press, The Netherlands, pp 356-365.

European Environment Agency, 2007. Europe's environmentThe fourth assessment, Office for Official Publications of the European Communities, Luxembourg.

ISO, International Organization for Standardization 2006a. International Standard ISO 14040:2006 Environmental management - Life cycle assessment - Principles and framework, International Organization for Standardization.

ISO, International Organization for Standardization 2006b. International Standard ISO 14044:2006 Environmental management - Life cycle assessment - Requirements and guidelines, International Organization for Standardization.

Kaziolas D.N., Zygomalas I., Stavroulakis G.E. and Baniotopoulos C.C., 2013. Environmental sustainability assessment methodologies for steel and timber structures. In: Proceedings of the 9th WSEAS International Conference on Energy, Environment, Ecosystems and Sustainable Development (EEESD'13), pp. 37-42, Lemesos - Cyprus.

The Netherlands Ministry of Housing, Spatial Planning and the Environment, 2000. Eco-Indicator 99, Manual for designers: A damage oriented method for Life Cycle Impact Assessment.

Zygomalas I., Efthymiou E., Baniotopoulos C. and Blok R. 2012. A newly developed Life Cycle Inventory (LCI) database for commonly used structural steel components. Structure and Infrastructure Engineering, Taylor \& Francis Group. Volume 8, Issue 12, pp. 1173-1181.

Zygomalas I. \& Baniotopoulos C.C. (2013) Uncertainty in life cycle assessment (LCA) induced by LCI data: the case of structural steel. Engineering Journal, American Institute of Steel Construction (AISC), Second Quarter 2013, Volume 50 , No. 2, pp. 117-128. 